\title{
Teaching Entrepreneurship by Using the "Student Enterprise Model” to Future Vocational Teachers
}

\author{
Ursula Småland Goth, Eldbjørg Marie Schön \\ Oslo and Akershus University College for Applied Sciences \\ Ursula.Smaaland.Goth@hioa.no
}

\begin{abstract}
A recent focus worldwide is on education to foster entrepreneurship, mostly at the college level. Norway's Knowledge Promotion Reform introduces entrepreneurial thinking already in upper-secondary education and gives to vocational teachers the task of preparing students in these areas. The Oslo and Akershus University College, Institute for Vocational Education, teaches entrepreneurship both on theoretical and practical level to students preparing to teach in public schools. This article examines the practical dissemination of entrepreneurship through the project "Student Enterprise," and examines how the targets of this module - those in training to be vocational teachers - perceived its relevance. The research question was pursued through a strategic literature search, a quantitative analysis of teaching assessments from 114 students (course evaluations), and a survey of 18 vocational teachers-in-training. The literature search and theories of Dreyfus \& Dreyfus and Schumpeter formed the basis for analysis and discussion. The "Student Enterprises" teaching plan and method aims to promote entrepreneurial thinking and convey direct experience to future vocational teachers, who will in turn impart these lessons to their students, with the implication that they will use the same model with their students. The results show that today's praxis is not effective with all vocational-teaching students as a method of preparing teachers to teach entrepreneurial skills. Authors found a high level of dissatisfaction among future vocational teachers with the Student Enterprises module, but the specifics of the dissatisfaction could not be clearly ascertained, suggesting a need for further assessment to better adapt this entrepreneurial pedagogy to students' needs.
\end{abstract}

Keywords: Entrepreneurship, vocational teacher, student enterprise, qualitative study, Norway

\section{Introduction}

Education reform has encouraged Norwegian public schools to be more self-reflexive about their methods and aims (Befring \& Tangen, 2008). A 2006 government directive presented a vision and strategic plan for Norway as a global leader in innovation and entrepreneurship, with the aim of deliberately cultivating initiative and creativity to develop new profitable businesses (Norwegian Ministry of Education, 2006). Changes in vocational education are part of reaching this goal, with that curriculum directed to provide practical knowledge, including entrepreneurship skills, relevant for students' future professions (Norwegian Ministry of Education, 1996). The European Union considers the dissemination of entrepreneurial skills to be an essential factor in fostering social welfare (Seikkula-Leino et al., 2012). Research from Finland shows a need for greater emphasis on entrepreneurship in vocational teacher education at both national and EU level (Sekkula-Leino et al., 2012. Sweden has also introduced changes in their vocational educational programs, also with a focus on entrepreneurship (Holmgren, Lundström, Olofsson \& Viklandet, 2005). Classroom teaching is one part of the curriculum, but hands-on, practical experience is another objective. This led to the introduction of several student-run canteens (student enterprises) in secondary schools, in both Sweden and Norway (Holmgren et al., 2005). Whether in the classroom or with hands-on projects, vocational teachers have a central role in disseminating knowledge and guidance to students.

Entrepreneurship education, especially at the pre-college level, is a relatively new area for Norway. Little research has been done assessing effectiveness of different pedagogical strategies (Olofsson, 2009), let alone strategies for teaching future primary and secondary teachers of entrepreneurship. In this article we examine a current program for teaching entrepreneurship to future teachers that is common in Norway -- the student enterprise -- and we assess how well this method meets the needs of future teachers. Using a quantitative approach, we investigate whether former and current vocational-teaching students experience the student enterprise project as relevant both on a theoretical and practical level. In making these assessments, it is important to distinguish between the program's content and teaching 
quality. Norwegian government White paper no. 27 (2001), addressing quality in education, asserts that it is duty of institutions to insure that curriculum content is relevant and attractive to the students' future profession, and to ensure that teaching and research are of first-rate quality and reflect changing market trends and national needs (Neequaye, Darkwa \& Amu, 2014). We assess here how well the student enterprise module for vocational teachers-in-training meets these standards and reflect on this module as a didactic tool.

Aim of the study and research question: In this study we aim to investigate the experience of students studying to be vocational-teachers in the course "Entrepreneurship" as part of a module in RM, the implementation of the project student enterprise relevant to their future work as a vocational teacher. This study will highlight:

- how students experience the dissemination of entrepreneurship and

- if current teaching practices are perceived as relevant for future professional practice

Definitions: Entrepreneurship is defined both as establishing new business and more fundamentally, the ability to see market opportunities and act on them (Goth \& Schön, 2014). Entrepreneurship skills are relevant to all areas of business, whether the enterprise is still being planned or is already long in operation. Entrepreneurship encompasses economic, social, and cultural factors (Norwegian Ministry of Education, 2009:7). Here, we define entrepreneurship as "a dynamic and social process where individuals, alone or in collaboration, identify opportunities and act upon these by transforming ideas into practical and purposeful activity, be it a social, cultural, or economic context." (Norwegian Ministry of Education, 2007).The pedagogical principles in entrepreneurship are summarized by Odegaard (2003) as; cooperation with the local community, project-oriented and interdisciplinary, problem-based, resultsoriented, experiential and participation. Young Enterprise is a nationwide non-profit organization established in 1997. The organization consists of a National Secretariat and 17 county organizations. Young Enterprise is a member of the European and the global umbrella organization "Junior Achievement Worldwide." Through various programs Young Enterprise offers training in entrepreneurship in both primary, secondary, and higher education, and operates at the intersection between schools, businesses, the public and private sectors (Young Entrepreneurship, 2014; Goth \& Schön, 2014).

Student Enterprises is an educational program for college and university students training to be vocational teachers. The program imparts knowledge of business-creation through the experience of working together to start-up, operate, and then decommission their own company over the course of one year (or less). These "companies" correspond to student enterprises in upper secondary education. The purpose of Student Enterprises is to prepare future vocational teachers in their forthcoming work of leading and guiding secondary students in their own student enterprises (Goth \& Schön, 2014). Project "Student Enterprise" is currently being implemented in second year of the Study Program Restaurant and Food Processing at the university college tough the module RM (Oslo and Akershus University College, 2011). RM Student enterprise is a learning strategy where the individual "learns by doing," with the aim of increasing student motivation and building skills vital to the future workplace (Goth \&Schön, 2014; Shen, Chou \& Hsiao, 2014). Focuses here are on social learning, development of action competence, and personal commitment, for instance, through students risking their own resources. This creative approach is disseminated as pedagogical entrepreneurship. Project Student Enterprise at higher education level is organized as cooperation between schools and the business community and provides meaningful learning by showing the connection between theory and practice.

The Norwegian Association of Local and Regional Authorities (KS) is the only employers' association and interest organization for municipalities, counties, and local public enterprises in Norway. Schools in Norway are under the umbrella of municipalities and counties. KS has promoted entrepreneurship as a natural part of the curriculum (Local government organization, 2014). In our article, we investigate entrepreneurship in the domain of restaurant operation and food processing at the Oslo and Akershus University College. Entrepreneurship Module RM2000 takes an active approach, with the student responsible for each step in the process. Similar modules in a previous study (Goth \&Schön, 2014) have a theoretical orientation. Vocational teacher education (here specifically in module RM) might be achieved through a three-year full-time program. Admission requirements are currently a trade certificate (certificate awarded on successful completion of a vocational-training course, and entitling the holder to practice the trade concerned) and relevant experience. The three-year full-time program at the higher education level prepares future vocational teachers in subjects such as leadership and working with youth enterprises in school. RM's goal is for each student to acquire skills that include innovation, 
creativity, and working with financial risk models as well as a wide variety of changing activities that go along with the commencement of new business. Participation in a Student Enterprises module is accordingly a prerequisite for a vocational teacher qualification. This occurs through the use of student enterprises as teaching qualification.

\section{Literature Review}

In Norway today, and throughout the Nordic countries, entrepreneurship education is at a high level, reflecting years of development and strategizing, with the Nordic Model internationally recognized (Chiu, 2013). The Nordic Model promotes entrepreneurship as a skill that is essential in today`s society (Sarasvathy and Venkataraman, 2011). This teaching method has its roots in Dreyfus \& Dreyfus's theory (1986). Entrepreneurship as part of education is increasing worldwide, but important pedagogical and didactic questions remain (Fayolle, 2013; Anaele, Adelakun, Dem \& Barfa, 2014). Fayolle stresses the importance of measuring the effectiveness of various pedagogical approaches to imparting entrepreneurial skills. More broadly, he argues both as teachers and researchers for taking a critical attitude to what are perhaps unconscious assumptions about what works. (Fayolle, 2013). The didactic model Fayolle and Gailly (2008) present emphasizes the importance of social networks to the development entrepreneurial opportunities. This can be made visible with a procedural approach to entrepreneurship, showing the importance of collaboration among stakeholders. It is in these collaborative processes possibility is born and ideas will be tested, refined, and tested again.

Entrepreneurship has effects on different societal levels simultaneously. Already in 1934, Schumpeter noted the importance to the economy, in terms of initiative and development; of individuals he termed "entrepreneurial" (Schumpeter, 1996). Rather than leaving entrepreneurship to arbitrarily distributed, idiosyncratic character traits, entrepreneurship research aims to both explain and help facilitate this key driver of economic development (Davidson \& Wiklund, 2001). Both micro and macro perspectives are needed for this inquiry and these authors argue for a wide variety of methodologies, noting that the study of entrepreneurship lies essentially outside the scope of entrepreneurial phenomenon itself. With entrepreneurship essentially about creating something new, the concepts of experience and growth are central. Fayolle \& Gailly (2015) found that students who had previous significant entrepreneurship exposure, the impact of entrepreneurship education was lower than for students with no previous knowledge in this field. Among obstacles to effective entrepreneurship education identified in a recent Norwegian study were lack of teachers' motivation and engagement, failure to incorporate the subject into the current examination system, and a need for curriculum and tool development (Chiu, 2013). Growth, motivation and experience are central concepts as well in Dewey's educational thinking, which we chose as an apt theoretical model for understanding entrepreneurship as a pedagogical problem (1997). Curriculum theory (Linde, 2000), with its focus on the teaching process, framework factors, learning materials, mediation model (Bjørnsrud, 1995:93), and the group-process model (Bjørnsrud, 1995:98) are also included in the discussion.

\section{Methodology}

The aims were addressed by a strategic literature search, a quantitative analysis of 114 course evaluations, and a survey based on 17 semi-structured interviews. We use these three methodological approaches to triangulate (Patton, 2002) our understanding of the vocational students' own experience.

Literature Search: Based on the keywords identified using a PICO (Population Intervention, Comparator, Outcome) form we undertook a systematic literature search (Patton, 2002) using the databases BIBSYS, Norart, ERIC, and Scopus. The keywords (Norwegian and English) used in the search were "entrepreneurship - relevant - and /or student enterprises and/or vocational teacher." The search found 60 matches; including six articles were analyzed in this article.

Course Evaluations: (assessment of academic progress and experienced teaching): Course evaluations are an evaluation form where students self-assess their academic progress of the various modules of the program. All vocational-teacher students at Oslo and Akershus University College fill out course evaluations after completing each module in the program. We obtained 114 individual evaluations for module E2000 (entrepreneurship \& product development) for the period 2007-2013. 
Survey: A survey with close-ended questions (either dichotomous or on a scale of 1 to 7 and based on the theoretical framework of Brinkmann (2010). 18 students completed the module in 2011. 17 students were present and all students completed the survey in full.

Analysis, Verification, and Hermeneutical Perspective: The author (ES) applied a discourse analysis (Patton, 2002) to the texts (the 114 course evaluations). With a limited access of 17 informants the representatively of the data could not be analyzed in a factor analysis, t-test and correlation analysis. Therefore both the analysis of course evaluations and survey data are shown as average calculation describing relevance. Relevance here includes the academic content, didactic approach and guidance and is shown as an average calculation. The questionnaire (survey data and course evaluation), is based on a scale of 1 to 7 . By checking on a scale from 1 to 7 shows the student / participant to what extent he or she agrees with the statement or claim ( 1 being "not very relevant" or "strongly disagree" and 7 "very relevant" or "strongly agree"; 4 means "neither agree nor disagree"). Ratings 1,2 , and 3 were pooled and assessed as not relevant; 5, 6 and 7 were combined as very relevant. The average of the responses was calculated and the higher the result, the more positive the assertion. By combining different methodological approaches (text analysis, course evaluation, and survey) the authors want to verify the results (Johannessen et al., 2010:42). Using three different approaches, we looked at conformity and divergence of the results while we triangulate the results (Patton, 2002). To analyze the students' "experience of relevance" we used a hermeneutic perspective. By that we could interpret and create meaning in the text. In keeping with our qualitative approach, we want to highlight how students experienced the situation, and through interpretation based analysis, build a bridge between the raw data and results. Within the interpretation of quantitative data, we had to deal with our own role, our assumptions, and consequences of the interpretation. Kvale \& Brinkmann (2009) show that dialogue is the basis for knowledge and has application to the problem of validating results. Therefore, we also give an account of the author's involvement and background so that the hermeneutical perspective becomes available to the reader.

The Authors' Background: Author ES has professional experience as cook and assistant professor within vocational training and head of the discussed module in the article. Author USG holds a master in economics and management and $\mathrm{PhD}$ and has responsibility for the subject content for master students but in another academic field. The structure of the study and the questioner was developed in a cooperative manner. Data were collected by ES and analyzed jointly by the authors. To verify these data by both authors independently from each other analyzed and interpreted the data. Thereafter the authors discussed and verified the data. Both authors participated in the writing of the article.

Ethical Clearance: The study was approved by the Norwegian Community Data (Privacy Ombudsman) and has received an approval - registered as 35931/2/IB. The recommended guidelines and research ethics principles were followed throughout the study.

\section{Results}

The section has two parts. The first results are based on 114 course evaluations for seven years and found in section "Course evaluations" The results of the survey are to found in section "Survey data".

\section{Course evaluation}

Table 1: Dissemination of Entrepreneurship: The Student's Experience

\begin{tabular}{lllllll}
\hline & RM 06* & RM 07 & RM08 & RM09 & RM10 & RM11 \\
Question & $2007 / 08$ & $2008 / 09$ & $2009 / 10$ & $2010 / 11$ & $2011 / 12$ & $2012 / 13$ \\
$\begin{array}{l}\text { How relevant is the practical } \\
\text { approach of student enterprise }\end{array}$ & $\mathbf{2 . 4}$ & $\mathbf{1 . 7}$ & $\mathbf{2 . 4}$ & $\mathbf{3 . 3}$ & $\mathbf{2 . 5}$ & $\mathbf{2 . 2}$ \\
$\begin{array}{l}\text { for future employment as } \\
\text { vocational teacher in the }\end{array}$ & & & & & & \\
modules subjects (RM)? & & & & & & \\
\hline
\end{tabular}

Values shown in the table are based on a scale from 1 ("highly relevant") to 6 ("not relevant"). RM stands for the program plan "restaurant and food processing," followed by the number indicating the school year at the commencement of the study. Table 1 is based on the standard course evaluation used universitywide. The results show the changing average over six consecutive academic years of students' assessment of the student-enterprise project. As noted, that project is an aspect of the module RM2000, which overall 
includes both theoretical and practical training in entrepreneurship. In particular, students were asked to assess the student-enterprise project in which they participated at university college as to its relevance to their future work teaching entrepreneurship at the secondary level. Table 1 reports the change in average response to this question of each class over six years, as drawn from course evaluations ( $\mathrm{n}=114$ ov er six years). The questionnaire is a standardized instrument used for all of the department's course evaluations. Table 1 shows the experience of relevance for future work as a vocational teacher. Here we see that the department's average value, over the years in question, was 2 . The table gives no indication of the individual student experience average over a given time period. We found that student dissatisfaction tended to relate to the examination system or correlate with prior entrepreneurial knowledge and experience. We found further that students enrolled 2010/2011, which submitted responses in 2012, is lower than average. In that year a new training manager was appointed.

Survey Data: While the course evaluation covered the entire module, Survey data show the divergence between individual data and form basis for discussion in connection with the preparation of new curricula for Vocational Teacher Education Program in Restaurant and food processing and the examination system. The answers reflecting the opinion of those 17 students are included in the study. These data are shown in the sections below and the wording of the question is presented as a header in the various sub-sections

"How relevant do you think is the knowledge of entrepreneurship for those becoming vocational teachers?"

Figure 1: Experience of university college students studying to be secondary-level vocational teachers as to relevance of RM2000 (including both practical and theoretical aspects) to future teaching of entrepreneurship

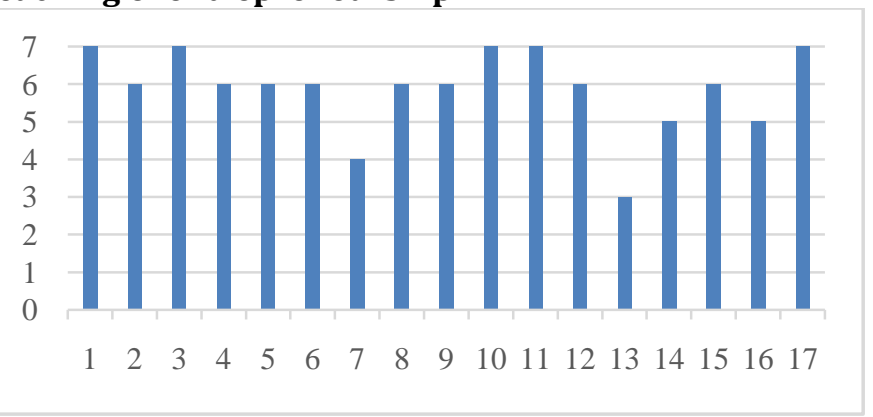

Figure 1 shows the individual experience of relevance to RM2000, including both the module's practical and theoretical aspects, to future teaching of entrepreneurship at the secondary level. Average calculations showed a relevance of 5.8 on a scale of 1 to 7 with 1 being "least relevant" and 7 being "most relevant".

"How relevant do you find the training (teaching approach) in entrepreneurship for you as future vocational teacher? “

Figure 2: Experience of learning about Entrepreneurship in Practical way through the StudentEnterprise project

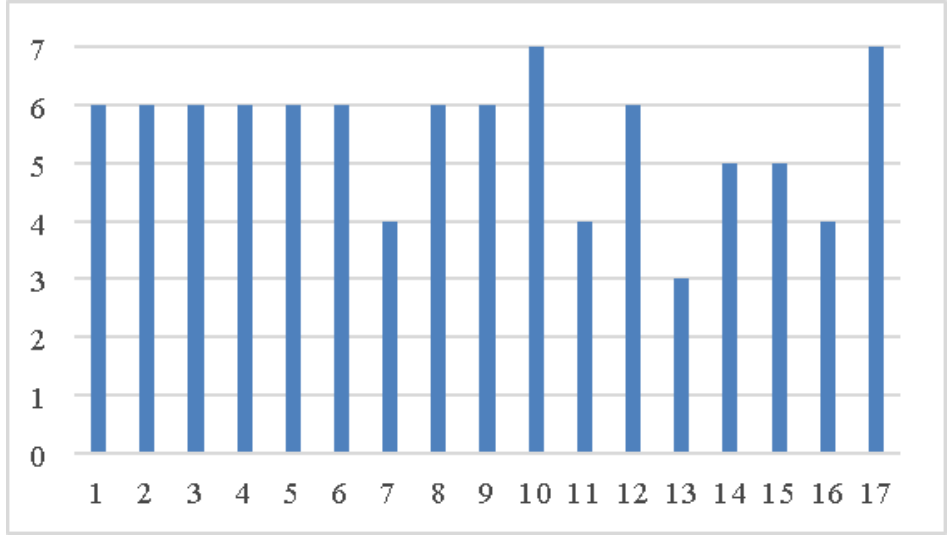


The height of the columns shows the different students' (1to17) experience of relevance with 1 being "not at all relevant" and 7 being "completely relevant". Figure 2 suggests that students in the 2012/2013 academic year surveyed just after completing the student-enterprise project experienced it as relevant. Responses were on a scale from 1 to 7 and the average value was 5.4

"To what extent do you feel content and working methods in the module RM2000 is relevant to your work as a teacher later?"

Figure 3: Student entrepreneurship as experienced during vocational training at higher education is didactically relevant to teaching in secondary schools

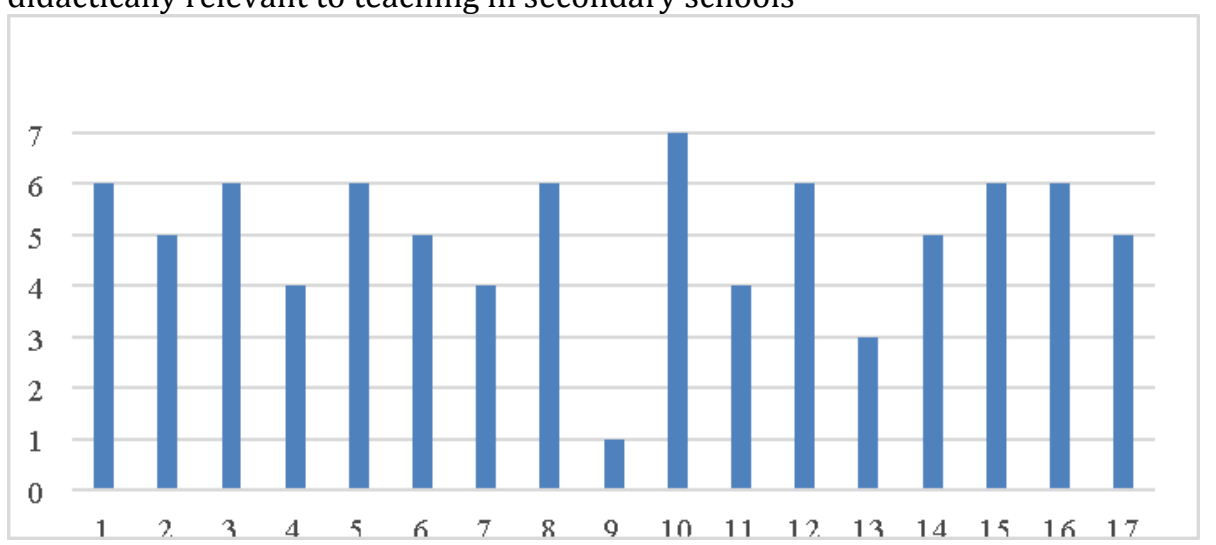

Figure 3 shows that the curriculum and working method was not found to be relevant by all students. The majority of students included in this study have worked previously as vocational teachers and trainers. Therefore their opinion was seen to be of highest relevance. As Figure 3 shows the working method had an overall positive outcome but was not found to be relevant by all students. The answers range from non-relevant (1) to very relevant (7) and have a calculated average value of 5.

"To what extent do you experience the work method during the project student enterprise relevant to your future teaching in secondary schools?"

Figure 4: Motivation for using a student-enterprise project with future secondary students in future teaching situations

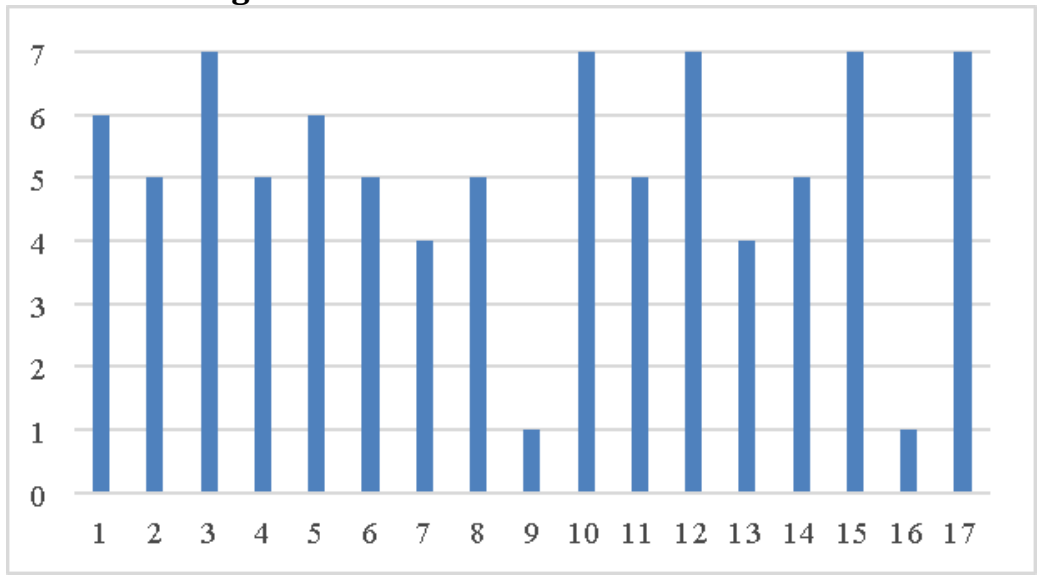

The height of the columns show the different students' (1to17) experience of relevance on a scale of 1 to 7 , with 1 being "least motivated" and 7 being "most motivated." Figure 4 shows the different assessments of perceived usefulness of a student-enterprise project as a pedagogical tool for secondary students. Four of the 17 students who had from neutral to very negative reviews of their own experiences with studententerprise project at the university college nonetheless said that they saw the value of such projects at the secondary level and saw that it was relevant that they have experience in implementing and leading such as project as a teacher in a high school. The average value of the experience of relevance was 5.1.

"To what extent are you confident that you will be able to direct youth in a Student Enterprise project at the secondary level?" 
Figure 5: Perceived confidence and execution capacity

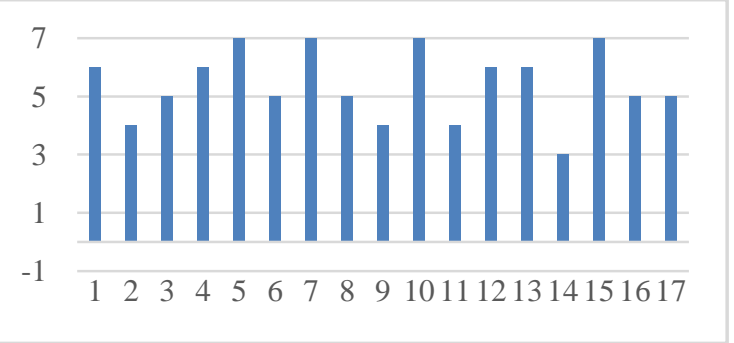

The height of the columns shows the different students' (1to17) experience of confidence on a scale of 1 to 7, with 1 being "least confident" and 7 being "most confident." Figure 5 shows that 13 of 17 students found that their participation in student-enterprise project made them feel confident to direct such a program for their own future students at the secondary level. The average reported confidence of 5.4 on a 1-to-7 scale indicates that on average, students felt their participation prepared them to use this technique.

"Is the student-enterprise a learning activity you would recommend and implement in secondary education?"

Figure 6: Project"Student enterprise": intention to use in vocational training in secondary education

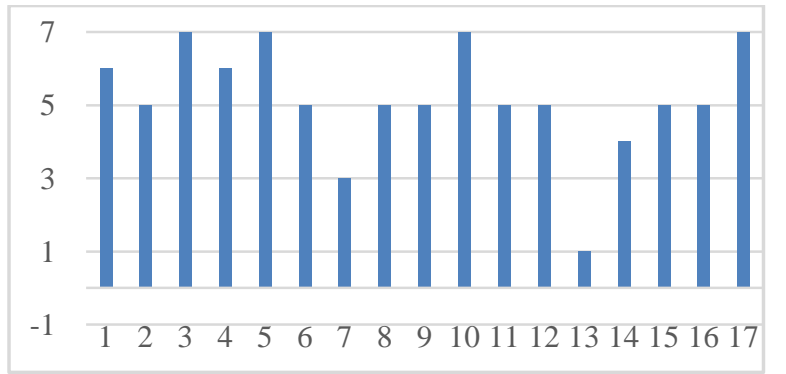

The height of the columns shows the different students' (1 to17) experience of relevance on a scale of 1 to 7, with 1 being "least likely to recommend and implement" and 7 being "extremely likely to recommend and implement."Figure 6 shows the individual students' motivation and intention to recommend the use of student enterprise in their future professional life. As shown in Figure 6, a total of 14 out of 17 students wanted to promote student enterprise in their own work as vocational teachers, with 4 students saying they would be "extremely likely to recommend and implement" such project. This assessment was not dependent on the self-perceived ability.

Discussion: Our results showed that successful implementation of entrepreneurship education for vocational teachers in training, depends on the precise curriculum, the future vocational teachers' motivation, and the relation of the coursework to the examination system. Similar results were found in a recent Norwegian study (Chiu, 2013).

Curriculum: Vocational education is oriented around the knowledge needed to practice a certain skilled job, involving knowledge of different and varying types and dimensions (Hiim \& Hippe, 2007). The module on entrepreneurship, as conveyed in RM2000, is situated within the framework of vocational education. Topics include new technology, fostering knowledge, distribution, and marketing (Schumpeter, 1996). The overall goal is to promote innovation by teaching skills needed to take advantage of market needs and opportunities (Anaele et al., 2014). Student enterprises involve solving practical problems in these domains in a grounded, real-world context. Via workshop learning, entrepreneurial thinking is promoted and the fragmentation of knowledge that is always a danger in abstract, classroom-based methods can be avoided. Student enterprises facilitate learning through practice and personal experience, fostering group interaction and collective response in the face of inevitable challenges (Mjelde, 2002).With student-enterprise projects embedded, vocational education integrates both the academic and the practical dimensions. Results showed students with previous knowledge of entrepreneurship expressed less satisfaction with the module than inexperienced students. Similar findings emerge from a 
study by Fayolle (2015) suggesting the importance of teachers continually reflection on their didactic approach to avoid stagnation (Fayolle, 2013).

Motivation: Entrepreneurship is conveyed through a process of "scaffolding" (Vygotsky, 1997), which describes how the facilitator can support the learning of students by gradually transferring responsibility. Over the course of module 2000 students are given incrementally increased responsibility and are compelled, individually and collectively, to test various strategies, encouraging development of strategic breadth and flexibility. This practical, hands-on learning approach helps students contribute to the mastery of new situations and fosters skills transferrable to new contexts (Befring \& Tangen, 2008). As contexts and market-trends change over time, reflecting on the experience of curriculum is seen to be highly relevant (Neeuwaye, Darkwa \& Amu, 2014). Literature shows here that entrepreneurship education holds an overall high satisfaction (Fayolle \& Gailly, 2015; Shen, Shou \& Hsiao, 2014). In our study, 2 of the 14 students (students numbers 9 and 13) tended to be negative overall about their experience with student enterprises, which invites a further look into what could be done to make the project more effective. Improving the student-enterprise project is important because it integrates in a concrete, practical way many themes in entrepreneurship pedagogy, an increasingly important aspect of vocational education, which sometimes suffers today from a narrow concept of what constitutes knowledge (Hiim \& Hippe, 2001); often leaving students with a sense that coursework is not relevant to real-world problems.

Examination system: Our results here show the experience of the student-enterprise project was regarded positively by students of vocational teaching, with as well some negative responses and some uncertainty as to whether these students would use this technique with their own future students. The negative reactions were based on the examination form. Here we can presume these students interpret their experiences through their own intentions, plans, and projects (Hiim \& Hippe, 2007). Examination in module 2000 was until recently partly public. In the course of the student-enterprise project each individual group developed their own product, which would be offered for sale at the end of the module in the entrance hall of the University College, where co-students for other faculties and institutes had the opinion of buying it. Student groups who did not develop a "popular product" could get here a negative experience (Goth \& Schön, 2014). With further insights from the perspectives of Dewey (1997) and Vygotsky (1997), we might speculate that the cause of the partial negative reactions found might lie in the lack of good fit between business/market needs and the student-enterprise projects pursued, or issues with how these projects were guided.

\section{Conclusion}

The authors conclude that a sample of university college students studying to be vocational teachers find both interest and relevance in the student-enterprise project. What they learned overall is relevant to their own practice in the future - but that a few felt dissatisfied with the project and they and a few others were uncertain that they would themselves use this form of teaching with their future students. We could identify that the curriculum in the future vocational teachers' motivation and the examination system are critical factors for successful dissemination of entrepreneurship by student- enterprise projects.

Acknowledgement \& Authors Contribution: The authors would like to thank the participants of the survey and the anonymous peer reviewer for their advices and recommendations. ES and UGS are coauthors of this article and UGS holds the role as corresponding author. ES initiated the project and UGS supervised it. ES was responsible for obtaining the data and USG for ethics approval. The authors worked together analyzing and interpreting the results.

\section{References}

Anaele, E., Adelakun, O., Dem, I. \& Barfa, G. (2014). Strategies or revitalizing the implementation of entrepreneurship education in technical, vocational education and training (TVET) to enhance selfemployment in Nigeria. British Journal of Education, 2(4), 50-62.

Chiu, R. (2012). Entrepreneurship education in the Nordic countries. Strategy implementation and good practices. Nordic innovation report 2012:24. Oslo: Norden.

Befring, E. \& Tangen, R. (2008). Spesialpedagogikk (Translated from Norwegian: special needs education). Oslo: Cappelen Akademiske forlag. 
Bjørnsrud, H. (1995). Læreplanutvikling og lærersamarbeid (Translated from Norwegian: curriculum development). Oslo: Universitetsforlaget.

Brinkmann, S. K. (2010).Detkvalitativeforskningsintervju. (Translated from Norwegian: The qualitative research interview). Oslo: Gyldendal Akademisk.

Davidson, P. \& Wiklund, J. (2001). Levels of analysis in entrepreneurship research: Current research practice and suggestions for the future. Entrepreneurship Theory and Practice, 25(4), 81-100.

Dewey, J. (1997). Experience \& Education. John Reprint Edition. PN.com: Simon \& Brown.

Dreyfus, H. \& Dreyfus, S. (1986). Mind over Machine: Power of Human Intuition and Expertise in the Era of the Computer. New York: Free Press.

Fayolle, A. \& Gailly, B. (2008). From Craft to Science: Teaching Models and Learning Processes in Entrepreneurship Education. Journal of European Industrial Training 32, 569-593.

Fayolle, A. (2013). Personal views on the future of entrepreneurship education. Entrepreneurship \& Regional Development. An International Journal, 25(7-8), 692 - $701 . \quad$ DOI: 10.1080/08985626.2013.821318.

Fayolle, A. \& Gailly, B. (2015). The Impact of Entrepreneurship Education on Entrepreneurial Attitudes and Intention: Hysteresis and Persistence. Journal of Small Business Management, 53(1), 75-93. DOI: $10.1111 /$ jsbm.12065.

Goth, U. S. \& Schön, E. (2014). Learning by doing. Nordic Journal of Vocational Education and Training. (4), 1-21. Retrieved March $5^{\text {th }}, 2015$ from http://www.nordyrk.org/.

Halvorsen, K. (2011). Å forske på samfunnet - En innføring i samfunnsvitenskapelig metode (Translated from Norwegian: To research on society - an introduction to methods in social science) (5. edt.). Oslo: Cappelen Akademisk Forlag.

Hiim, H. \& Hippe, E. (2001). Å utdanne professionelle yrkesutøvere. (Translated from Norwegian: To educate professional practitioner). Yrkesdidaktikkogyrkeskunnskap (Vocational didactics and knowledge). Oslo: Gyldendahlakademisk.

Holmgren, C., Lundström, A., Olofsson, A. \& Viklands, I. (2005). Interrelated effects of entrepreneurship educations programs supported by local, regional and/or national authorities. Paper presented at the IntEnt-conference in Gilford, July 10-13 ${ }^{\text {th }}, 2005$.

Johannessen, A., Tufte, P. \& Christoffersen, L. (2010).Introduksjon til samfunnsvitenskapelig metode (Translated from Norwegian: Introduction to methods in social science).Oslo: Abstrakt forlag AS.

Kvale, S. \& Brinkmann, S. (2009). Det kvalitative forskningsintervju. (Translated from Norwegian: The qualitative research interview)Oslo: Gyldendalakademisk.

Larsen, A. (2007). En enklere metode: veiledning i samfunnsvitenskapelig forskningsmetode. (Translated from Norwegian: A simple method: guidance as method in social science)Bergen: Fagbokforlaget Vigmostad \& Bjerke AS.

Linde, G. (2000). Det skani veta! En introduksjon tillläroplansteori. (Translated from Swedish: This we should approve! An introduction to curriculum theory) Lund: Studentlitteratur.

Mjelde, L. (2002). Yrkenes pedagogikk; fra arbeid til læring - fra læring til arbeid. (Translated from Norwegian: Vocational pedagogic; from work to learning - from learning to work) Oslo: Yrkeslitteratur.

Local government organization. (2014). March 12, 2015 from http://www.ks.no/tema/Om-KS/KS-inEnglish/About-KS/.

Napier, G., Rouvinen, P., Johansson, D., Finnbjörnsson, T., Solberg, E. \& Pedersen, K. (2013). Nordic Growth Entrepreneurship Review 2012.0slo: Nordic Innovation. Retrieved on March 4, 2015 from http://www.nordicinnovation.org/Global/_Publications/Reports/2013/NGER_2012_summaryRep ort_2013_web.pdf.

Neequaye, N. K., Darkwa, S. \& Amu, M. E. K. (2014). Students 'perspectives of the food and nutrition program at the University of Cape Coast Home Economics department and its implication on curriculum change. Science Journal of Education, 2(1), 4-11. Doi: 1011648/j.sjedu.2014020.12.

Norwegian Ministry of Education. (2009). Entrepreneurship in Education and Training from compulsory school to higher education 2009-2014. Oslo: Ministry of Education. Retrieved on March 9, 2015fromhttps://www.regjeringen.no/globalassets/upload/kd/vedlegg/uh/rapporter_og_planer /entrepenorskap_09_nett.pdf .

NorwegianMinistryofEducation. (2007). Entreprenørskap i utdanningen - fra grunnskole til høyere utdanning 2009 -2014. (Translated from Norwegian: Entrepreneurship in education- from primary to higher education). Oslo: Ministry of Education.

Norwegian Ministry of Education (2006). Se mulighetene og gjør noe med dem- strategi for entreprenørskap i utdanningen, 2004-2008. (Translated from Norwegian: Look at the possibilities and do something with them - a strategy for entrepreneurship in education, 2004-2008). 0slo: 
$\begin{array}{lllll}\text { Kunnskapsdepartementet. } & \text { February } & 15, & 2015 & \text { from }\end{array}$ http://www.regjeringen.no/nb/dokumentarkiv/Regjeringen-Bondevik-II/ufd/Rapporter-og planer/Planer/2004/se-mulighetene-og-gjor-noe-med-dem.html?id=102074.

Norwegian Ministry of Education. (1996). Læreplanverk for den 10 årigegrunnskolen (L97). (Translated from Norwegian: National curriculum for the 10 years of primary and lower secondary school). Oslo: Nasjonal læremiddelsenteret. RetrievedFebruary, $15 \quad 2015$ from http://www.regjeringen.no/nb/dep/kd/dok/nouer/2003/nou-2003-16/13/2/4.html?id=370715

Ødegaard, I. R. (2008).Entrepreneurship in Education in Norway? In Remmele, B., Schmette, M. \& Seeber, G. (eds). EducatingEntrepreneurship. Wiesbaden: Deutscher Universitäts-Verlag. Pp13-88. Doi: 10.1007/978-3-8350-5480-6_3

Olofsson, A. (2009). Entreprenörskapsutbildning i skolaochsamhälle. - Formering av en ny pedagogisk identitet? Utbildningsvetenskapelige studier 2009. (Translated from Swedish: Entrepreneurship education in school and society. - Shaping of a new pedagogical identity ) Härnösand: Mittuniversitetet. $\quad$ Retrieved 5Mars, 2015 from http://www.divaportal.org/smash/get/diva2:224057/FULLTEXT01.pdf.

Oslo and Akershus University College. (2011). Fagplan for Yrkesfaglærerutdanning i Restaurant og matfag. (Translated from Norwegian: Curriculum for vocational teacher training in Restaurant and Food Processing). Module 2000: Product Development, Entrepreneurship, and Traditional food. Oslo: Oslo and Akershus University College.

Patton, M. Q. (2002). Qualitative Research \& Evaluation Methods. Thousand Oaks, CA: Sage.

Sarasvathy, S., \&Venkataraman, S. (2011). Entrepreneurship as Method: Open Questions for an Entrepreneurial Future. Entrepreneurship Theory and Practice 35(1):113-135. DOI: 10.1111/j.15406520.2010.

Seikkula-Leino, J., Ruskovaara, E., Hannula, H. \& Saarivirta, T. (2012). Facing the Changing Demands of Europe: Integrating Entrepreneurship Education in Finnish Teacher Training Curricula. European Educational Research Journal, 11(3) 382-399.doi: 10.2304/eerj.2012.11.3.382.

Shen, C. H., Chou, C. M. \& Hisao, H. C. (2014). Applications and Effectiveness of Cooperative Teaching Strategies in Entrepreneurship Education. In Jeong et al. (eds.) Advances in Computer Science and Its Applications. Heidelberg: Springer Verlag. Doi: 10.1007/978-3-642-41674-3_110.

Schumpeter, J. (1996). The Theory of Economic Development.London: TransactionBooks.

Ungt entreprenørskap. (2014). Ungt entreprenørskap. (Translated from Norwegian: Young entrepreneurship) Retrieved Mars03, 2015 from http://www.ue.no.

Vygotsky, L. S. (1997). The collected works of L. S. Vygotsky. Vol. 4: The history of the development of higher mental functions I R. W. Rieber (Red) New York: Plenum Press.

White paper No 27 (2000-2001) Norway. (2001) Do your duty-Claim your right. Ministry of Education. Retrieved 5 Mars, 2015 from https://www.regjeringen.no/nb/dokumenter/stmeld-nr-27-20002001-/id194247/?docId=STM200020010027000DDDEPIS\&ch=1\&q

Young entrepreneurship. (2015). Retrieved 5 Mars, 2015 from http://www.ue.no/Oslo. 